\title{
NUTRIENT FORAMINA ARCHITECTURE IN METACARPAL AND METATARSAL BONES
}

\section{Jyothinath Kothapalli *.}

* Assistant Professor, Department of Anatomy, Maheshwara medical college\& hospital, Chitkul, Isnapur, Patancheru, Telangana, India.

\section{ABSTRACT}

Nutrient foramen (NF) conducts blood vessels which are chief nutritional source to bones. The anatomical knowledge of nutrient foramina plays vital role in certain operative procedures to preserve the circulation. Details of NF in metacarpals and metatarsals is essential in reconstruction surgeries. This study designed to assess the architecture of nutrient foramina over metacarpal and metatarsal shafts. For this, a total 400 metacarpal and 400 metatarsal bones were collected. All bones are examined for details of number, position, location and direction of nutrient foramina on shaft. Foraminal index was calculated by using Hughes formula. Majority bones are having single nutrient foramen (79.7\% metacarpals, $79.5 \%$ metatarsals), double nutrient foramina was situated in very few metacarpals and metatarsals. Nutrient foramina are situated over medial surface of $1^{\text {st }} \& 2^{\text {nd }}$ metacarpals and $4^{\text {th }} \& 5^{\text {th }}$ metatarsal bones, whereas other bones have nutrient foramina over lateral surface of shaft. The anatomical and morphological details of nutrient foramina is beneficial for orthopedic and plastic surgeries during vascularized bone microsurgery and in bone grafts.

KEY WORDS: Nutrent foramen (NF), Metacarpals, Metatarsals, Faraminal Index (F.I).

Address for Correspondence: Dr. Jyothinath Kothapalli, Assistant Professor, Department of Anatomy, Maheshwara Medical College\& Hospital, Chitkul, Isnapur, Patancheru, Sangareddy, Telangana, India. E-Mail: kjyothinath@gmail.com

Access this Article online

Quick Response code

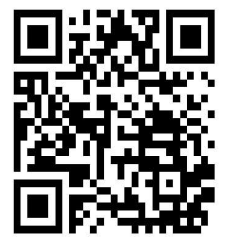

DOI: $10.16965 /$ ijar.2018.359
Journal Information

\section{International Journal of Anatomy and Research}

ICV for 2016 ISSN (E) 2321-4287 | ISSN (P) 2321-8967

90.30

https://www.ijmhr.org/ijar.htm

DOI-Prefix: https://dx.doi.org/10.16965/ijar

\section{Article Information}

Received: 14 Aug 2018

Peer Review: 16 Aug 2018

Revised: None
Accepted: 03 Oct 2018

Published (O): 05 Nov 2018

Published (P): 05 Nov 2018

\section{INTRODUCTION}

The metacarpals of hand skeleton and metatarsals of foot skeleton are termed as short or miniature long bones with inbuilt longitudinal and collective transverse arch. They differ from other long bones by having single epiphysis at only one end [1].

The metacarpals and metatarsals are chiefly supplied by nutrient artery along with periosteal and epiphyseal arteries. Being chief nutritional support to the bone, it plays key role in healing and union of fractures [2]. Nutrient artery transmits through nutrient foramen. Knowing about nutrient artery is essential for surgeons to preserve vessels in free vascularized bone grafts, which is essential to promote fracture repair and for the survival of osteocytes and osteoblasts [3].

The anatomical knowledge about nutrient foramina is useful in orthopedic surgeries, bone grafts, vascularized bone microsurgery, transplantations and reconstruction of fractured sites [4]. Several studies reported details of nutrient foramen in metacarpals and metatarsals separately. Due to the literature gap this study was designed to assess the architecture of nutrient foramen in metacarpal and metatarsal bones included their number, position, direction and foraminal index. 


\section{MATERIALS AND METHODS}

For the present study a total 400 metacarpal and 400 metatarsal bones were collected from Department of Anatomy of MNR Medical College and Hospital, Sangareddy and Maheshwara Medical College, Patancheru, Telangana. Bones with fractures, grossly pathological, abnormal and malformed bones were excluded from the study.

All the collected bones were examined for

1. Number of nutrient foramina

2. Position of nutrient foramina on shaft - medial and lateral surface

3. Distance of nutrient foramina from the base of bone.

\section{Direction of nutrient foramina.}

Vernier's caliper was used to measure the length of bones and to ensure the direction of nutrient foramina thin needle was used. Alone, Diaphyseal nutrient foramina through which main nutrient artery passes were studied. Epiphyseal and other vascular foramens were not considered. Forminal index was calculated by Hughes formula [5].

Foraminal index $=D / L \times 100$

$* D=$ Distance of nutrient foramina from base of the bone.

$* \mathrm{~L}=$ Total length of bone.

Table 1: Total number of nutrient foramina over the shaft of long bones.

\begin{tabular}{|c|c|c|c|c|c|c|c|c|c|c|c|}
\hline \multicolumn{2}{|c|}{ Bone } & \multicolumn{5}{|c|}{ Metacarpals } & \multicolumn{5}{c|}{ Metatarsals } \\
\cline { 2 - 14 } & $1^{\text {st }}$ & $2^{\text {nd }}$ & $3^{\text {rd }}$ & $4^{\text {th }}$ & $5^{\text {th. }}$ & $1^{\text {st }}$ & $2^{\text {nd }}$ & $3^{\text {rd }}$ & $4^{\text {th }}$ & $5^{\text {th }}$ \\
\hline \multirow{2}{*}{$\begin{array}{c}\text { Total bones } \\
\text { studied }\end{array}$} & Rt. & 40 & 40 & 40 & 40 & 40 & 40 & 40 & 40 & 40 & 40 \\
\cline { 2 - 14 } & Lt. & 40 & 40 & 40 & 40 & 40 & 40 & 40 & 40 & 40 & 40 \\
\hline \multirow{2}{*}{$\begin{array}{c}\text { Number of } \\
\text { foramina }\end{array}$} & 0 & 2 & 9 & 5 & 8 & 4 & 4 & 2 & 2 & 1 & 4 \\
\cline { 2 - 13 } & 1 & 68 & 57 & 66 & 65 & 63 & 55 & 69 & 63 & 67 & 64 \\
\cline { 2 - 13 } & 2 & 10 & 14 & 9 & 7 & 13 & 21 & 9 & 15 & 12 & 12 \\
\hline
\end{tabular}

Fig. 1: Location of nutrient foramina over the shaft of metacarpal bones.

\section{Location of nutrient faramina over metacarpals}

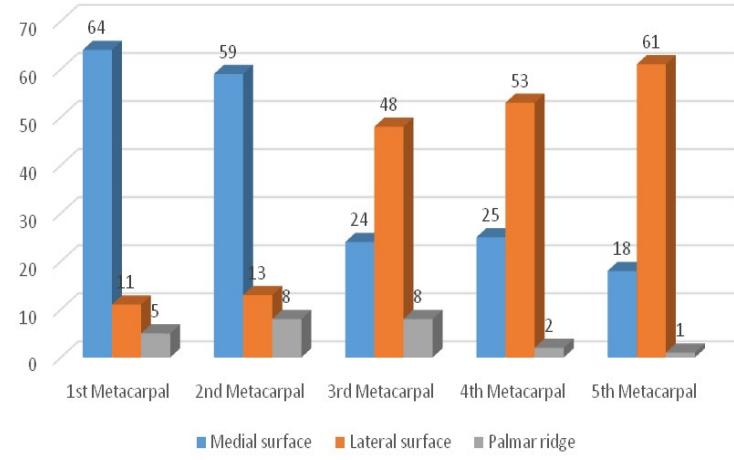

Fig. 2: Location of nutrient foramina over the shaft of metatarsal bones.

\section{Location of nutrient faramina over metatarsals}

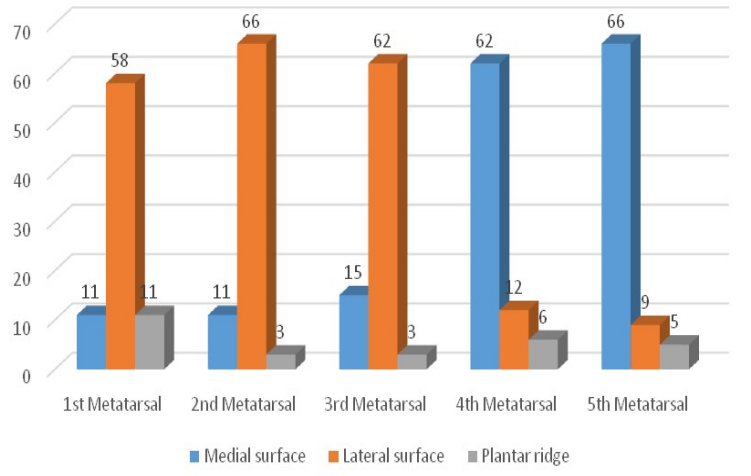

Table 2: Position of nutrient foramina over proximal, middle and distal parts of shaft of the metacarpals and metatarsals.

\begin{tabular}{|c|c|c|c|c|c|c|c|c|c|c|c|}
\hline \multirow{2}{*}{ Bone } & \multicolumn{5}{|c|}{ Metacarpals } & \multicolumn{5}{c|}{ Metatarsals } \\
\cline { 2 - 14 } & $1^{\text {st }}$ & $2^{\text {nd }}$ & $3^{\text {rd }}$ & $4^{\text {th }}$ & $5^{\text {th }}$ & $1^{\text {st }}$ & $2^{\text {nd }}$ & $3^{\text {rd }}$ & $4^{\text {th }}$ & $5^{\text {th }}$ \\
\hline $\begin{array}{c}\text { Position of } \\
\text { foramina over } \\
\text { shaft }\end{array}$ & $\mathrm{P} 1 / 3$ & 7 & 6 & 14 & 12 & 3 & 4 & 16 & 12 & 5 & 3 \\
\cline { 2 - 13 } & $\mathrm{M} 1 / 3$ & 67 & 70 & 59 & 65 & 76 & 62 & 62 & 60 & 73 & 73 \\
\hline \multicolumn{2}{|c|}{ Grand total } & 80 & 80 & 80 & 80 & 80 & 80 & 80 & 80 & 80 & 80 \\
\hline
\end{tabular}

$* \mathrm{P} 1 / \beta=$ Proximal $1 / 3, \mathrm{M} 1 / \beta=$ Middle $1 / 3, \mathrm{D} 1 / 3=$ Distal $1 / 3$.

Table 3: Range of Foraminal index (F.I) in metacarpal and metatarsal bones.

\begin{tabular}{|c|c|c|c|c|c|c|c|c|c|c|}
\hline \multirow{2}{*}{ Bone } & \multicolumn{4}{|c|}{ Metacarpals } & \multicolumn{5}{c|}{ Metatarsals } \\
\cline { 2 - 10 } & $1^{\text {st }}$ & $2^{\text {nd }}$ & $3^{\text {rd }}$ & $4^{\text {th }}$ & $5^{\text {th }}$ & $1^{\text {st }}$ & $2^{\text {nd }}$ & $3^{\text {rd }}$ & $4^{\text {th }}$ & $5^{\text {th }}$ \\
\hline $\begin{array}{c}\text { Range of Foraminal } \\
\text { index }\end{array}$ & $29.2-74.5$ & $28.4-78.8$ & $27.7-78.3$ & $27.1-76.8$ & $26.5-79.9$ & $25.1-73.6$ & $28.2-70.7$ & $30.1-81.3$ & $29.9-72.2$ & $28.6-75.4$ \\
\hline
\end{tabular}

\section{DISCUSSION}

The nutrient artery is a dominating blood vessel which supply major entity of a long bone along with diaphyseal, periosteal and epiphyseal arteries [6). The nutrient foramen is referred as an external opening of nutrient canal and is lied on the flexor aspect of bony shaft. The actual site of nutrient foramen is related to main center of ossification because corresponding nutrient vessels arises from the initial invasion of the ossifying cartilage [7-9]. In foetal life, nutrient foramen directed horizontally due to 
parallel growth at the two ends before epiphyseal appearance [10]. Currently, periosteal slip theory of Schwalbe and vascular theory of Hughes are widely accepted. For this study, 400 metacarpal and 400 metatarsal bones of both sides and both sexes were considered and assessed for nutrient foramen architecture over shaft.

Number of nutrient foramina: In this study, more number of $2^{\text {nd }} \& 5^{\text {th }}$ metacarpals and $1^{\text {st }} \&$ $3^{\text {rd }}$ metatarsals are showed two nutrient foramina over shaft than other bones. On average 63.7 bones showed single nutrient foramina over their shaft. (Table 1). Absence of nutrient foramen was seen in few bones. In such bones, periosteal artery take a lead and fulfills the sufficient bony needs $[11,12]$. Patake and Mysorekar, Sharimankar et al., Malukar and Joshi noticed single nutrient foramen over shaft of more number of metacarpal bones [12-14]. Anjali singla et al., in his study found single nutrient foramen over shaft of all five metacarpals [15].

\section{Position and location of nutrient foramina:}

Study by Patake and Mysorekar, Wood Jones et al., observed that nutrient foramina of $1^{\text {st }} \&$ $2^{\text {nd }}$ metatarsals, sometimes $3^{\text {rd }} \& 4^{\text {th }}$ metatarsals are situated on lateral surface $[12,16]$. Singh et al., observed that nutrient foramina of $4^{\text {th }}$ metatarsals on their medical surface [17].

In the present study, nutrient foramen of $1^{\text {st }} \&$ $2^{\text {nd }}$ metacarpals are located more on medical surface, whereas of $3^{\text {rd }}, 4^{\text {th }} \& 5^{\text {th }}$, foramina lied over lateral surface. In more number of $1^{\text {st }}, 2^{\text {nd }}$ $\& 3^{\text {rd }}$ metatarsals nutrient foramen are located over lateral surface of shaft, nearly uniform distribution of foramen over medial (40) and lateral (34) surfaces of $4^{\text {th }}$ metatarsals, whereas in $5^{\text {th }}$ metatarsals nutrient foramen are located over lateral surface of shaft. Study by Kumari Sandhya et al., stated that $100 \%$ of nutrient foramina lied over lateral surface of $1^{\text {st }}$ metatarsal, whereas in study by Anamica et al., none of the $1^{\text {st }}$ metatarsal showed NF over lateral surface $[11,18]$.

The majority nutrient foramen of all metacarpal and metatarsal bones are posited over middle $1 / 3$ of their shaft.

Fig. 3: Number of nutrient foramina over proximal, middle and distal parts shaft of metacarpal bones.

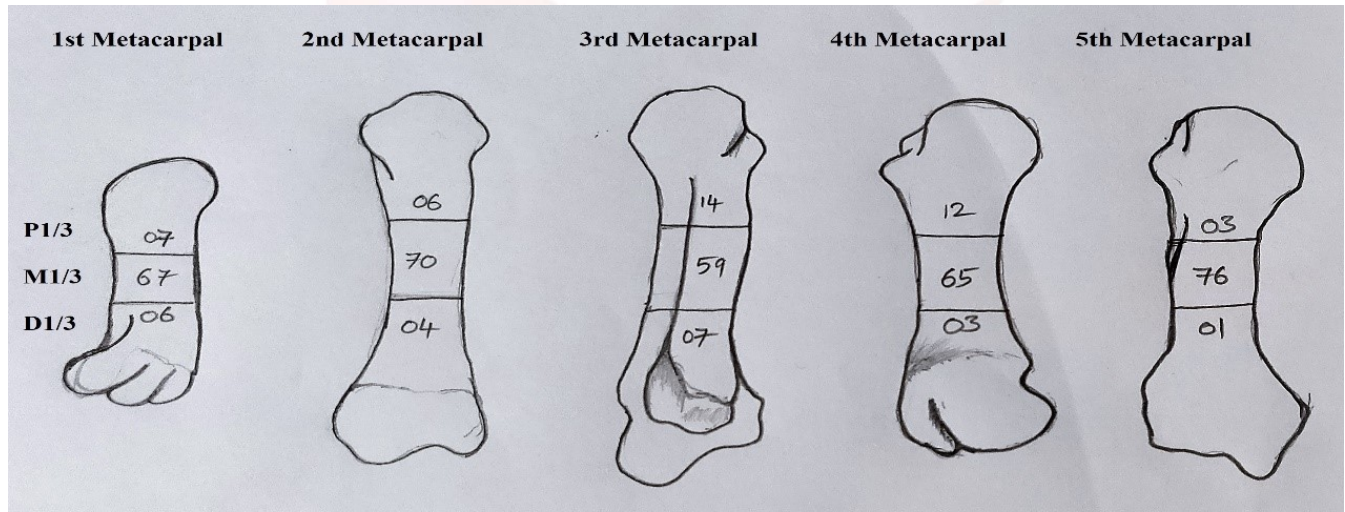

Fig. 4: Number of nutrient foramina over proximal, middle and distal parts shaft of metatarsal bones.

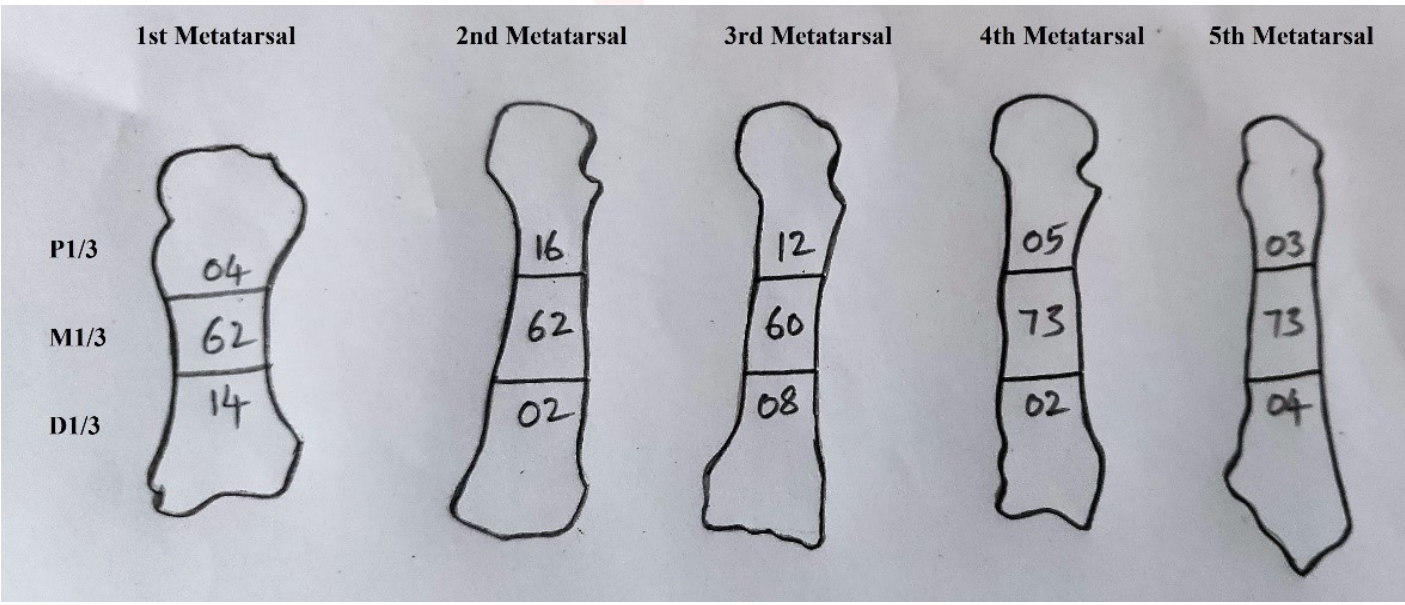


Table 4: Foraminal index Comparison of present with previous studies.

\begin{tabular}{|c|c|c|c|c|c|c|}
\hline Foraminal Index & $\begin{array}{c}\text { Patake \& } \\
\text { Mysorekar (1977) }\end{array}$ & $\begin{array}{c}\text { Shrimankar et } \\
\text { al. (2010) }\end{array}$ & $\begin{array}{c}\text { Anjali Singla et } \\
\text { al. (2016) }\end{array}$ & $\begin{array}{c}\text { Anamika K et } \\
\text { al. (2017) }\end{array}$ & $\begin{array}{c}\text { Kumari } \\
\text { Sandhya et al. } \\
\text { (2017) }\end{array}$ & $\begin{array}{c}\text { Present study } \\
\text { (2018) }\end{array}$ \\
\hline \multicolumn{2}{|c|}{ Metacarpals } & & \multicolumn{4}{|c|}{} \\
\hline $1^{\text {st }}$ & $40.02-80$ & 59.29 & $41.7-70.8$ & - & - & $29.2-74.5$ \\
\hline $2^{\text {nd }}$ & $28.3-69.36$ & 47.18 & $34.9-73.6$ & - & - & $28.4-78.8$ \\
\hline $3^{\text {rd }}$ & $29.41-76.60$ & 41.25 & $28.6-53.6$ & - & - & $27.7-78.3$ \\
\hline $4^{\text {th }}$ & $20.20-78.40$ & 43.87 & $30.6-64.4$ & - & - & $27.1-76.8$ \\
\hline $5^{\text {th }}$ & $31.70-63.04$ & 47.48 & $33.9-63.8$ & - & - & $26.5-79.9$ \\
\hline \multicolumn{2}{|c|}{ Metatarsals } & & & & & \\
\hline $1^{\text {st }}$ & $30.5-81.66$ & - & - & 65.3 & $32.78-71.15$ & $25.1-73.6$ \\
\hline $2^{\text {nd }}$ & $25.4-55.55$ & - & - & 43.6 & $17.91-63.33$ & $28.2-70.7$ \\
\hline $3^{\text {rd }}$ & $31.40-59.1$ & - & - & 44.4 & $29.57-56.89$ & $30.1-81.3$ \\
\hline $4^{\text {th }}$ & $36.40-62.91$ & - & - & 45.3 & $30.76-63.33$ & $29.9-72.2$ \\
\hline $5^{\text {th }}$ & $37.3-71.73$ & - & - & 47.5 & $14.28-49.18$ & $28.6-75.4$ \\
\hline
\end{tabular}

Direction of Nutrient canal: In this study, the direction of nutrient canal in all metacarpal and metatarsal bones are opposite to growing end. Malukar $\mathrm{O}$ and Hemang Joshi stated that direction of NF of all long bones are always way from the growing end (14).

Foraminal Index (F.I): The range of for Foraminal index in this study and its comparison with previous workers is compared (Table 4).

\section{CONCLUSION}

The knowledge about position and architectures of nutrient foramen is essential for the surgeons to perform vascular and reconstruction surgeries. The study results concluding that majority bones are having single nutrient foramen, double nutrient foramina was situated in very few metacarpals and metatarsals. Nutrient foramina are situated over medial surface of $1^{\text {st }}$ $\& 2^{\text {nd }}$ metacarpals and $4^{\text {th }} \& 5^{\text {th }}$ metatarsal bones, whereas other bones are having majority nutrient foramina over lateral surface of their shaft. The direction nutrient canal followed the growing end theory of the nutrient artery i.e. away from the growing end.

\section{Conflicts of Interests: None}

\section{REFERENCES}

[1]. Kizilkanat, E., Boyan, N., Ozsahin, E.T., Soames, R., Oguz, O. Location, number and clinical significance of nutrient foramina in human long bones. Ann Anat 2007; 189(1): 87-95.

[2]. McKeon KE, Johnson JE, McCormick JJ, Klein SE. The intraosseous and extraosseous vascular supply of the fifth metatarsal: implications for fifth metatar- sal osteotomy. Foot Ankle Int 2013; 34(1): 117-23.

[3]. Shamsunder Rao V, Jyothinath Kothapalli. The Diaphyseal nutrient foramina architecture a study on the human upper and lower limb long bones. IOSRJPBS 2014; 9(1) III: 36-4.

[4]. Prashanth, K.U., Murlimanju, B.V., Prabhu, L.V., Kumar, C.G., Pai, M.M., Dhananjaya, K.V.N. Morphological and topographical anatomy of nutrient foramina in the lower limb long bones and its clinical importance. Australas Med J 2011; 4(10): 530-7.

[5]. Hughes, $\mathrm{H}$. The factors determining the direction of the canal for the nutrient artery in the long bones of mammals and birds. Acta Anat 1952; 15:261-80.

[6]. McKeon, K.E., Johnson, J.E., McCormick, J.J., Klein, S.E. The intraosseous and extraosseous vascular supply of the fifth metatarsal: implications for fifth metatarsal osteotomy. Foot Ankle Int 2013; 34(1): 117-23

[7]. Payton CG, The position of the nutrient foramen anddirection of the nutrient canal in the long bones of themadder-fed pig, J Anat, 1934, 68(Pt 4):500510.

[8]. Longia GS, Ajmani ML, Saxena SK, Thomas RJ, Study ofdiaphyseal nutrient foramina in human long bones, ActaAnat (Basel), 1980, 107(4):399-406.

[9]. Meenakshi Parthasarathy, Sharmadhakl, Pushpalatha M, Parthasarathy KR, Krishnarjun P, Priyatham Tulasi. Morphological and Topographical Anatomy of Nutrient Foramina in Human Upper Limb Long Bones And Their Surgical Importance. 2016; 15(8)X: 80-85.

[10]. BV Murlimanju, KU Prashanth, Latha v Prabhu, Vasudha V Saralaya, Mangala M Pai, Rajalakshmi Rai. Morphological and topographical anatomy of nutrient foramina in human upper limb long bones and their surgical importance. Rom J Morphol Embryol 2011, 52(3):859-862.

[11]. Anamika K, Abhishek PS, Anuj J, Murlimanju BY, Divya P, Latha YP, Vasudha VS, Chitra PR, Ashwin RR, Teresa J, Prashanth KU. Morphology of Nutrient Foramina in Human Metatarsals and Their Clinical Importance. Med \& Health 2015; 10(1): 37-47. 
[12]. Patake, S.M., Mysorekar, V.R.. Diaphysial nutrient foramina in human metacarpals and metatarsals. J Anat 1977; 124(2): 299-304.

[13]. Shrimankar, D.P.S., Trivedi, D.J., Kariya, V.B. A study of nutrient foramina of the metacarpal bones. NJIRM 2010; 1(2): 16-21.

[14]. Malukar O, Joshi H. Diaphysial nutrient foramina in long bones and miniature long bones. NJIRM 2011; 2(2): 23-6.

[15].Anjali Singla, Gurdeep Kalsi, Nazir Masih, Tulika Gupta, Mahesh Sharma. Morphological and topographical anatomy of nutrient foramens in human metacarpals and their surgical importance. Surgical and Radiologic Anatomy 2017; 39(11):1227-1233.
[16]. Wood Jones F. Buchanan's Manual of Anatomy. London: Bailliere, Tindall and Cox 1946; 310, 367.

[17]. Singh I. Variations in the metatarsal bones. J Anat 1960; 94: 345-50.

[18]. Kumari Sandhya, K.K.P Singh. A Morphometric Study on the Nutrient Foramen of Metatarsal Bones in the Jharkhand Population. IOSR-JDMS 2017; 16(6) IX: 31-34.

How to cite this article:

Jyothinath Kothapalli. NUTRIENT FORAMINA ARCHITECTURE IN METACARPAL AND METATARSAL BONES. Int J Anat Res 2018;6(4.2):5848-5852. DOI: 10.16965/ijar.2018.359 